\title{
Pengembangan Padi Sawah Melalui Pendekatan Pengelolaan Ramah Lingkungan di Kabupaten Merauke
}

\section{Lowland Rice Development Through Environmentally Friendly Management Approaches in Merauke Regency}

\author{
Fransiskus Palobo*, Siska Tirajoh, Muhammad Thamrin
}

Balai Pengkajian Teknologi Pertanian Papua, Jl. Yahim No. 49, Sertani, Jayapura - Papua 99352

*E-mail Penulis Korespondensi: frans.merauke@gmail.com

\begin{abstract}
Most of the paddy rice farmers have not responded appropriately to the innovation of environmentally friendly rice field management, because they are not capable enough to support environmentally friendly and sustainable farming. The capacity of farmers to manage environmentally friendly paddy rice is closely related to individual behaviour towards technological innovations that are applied and disseminated. This study aimed to determine the productivity of paddy rice with an environmentally friendly management approach. The research was conducted in Merauke Regency, Papua Province, from July to November 2018 during the gadu planting season (MT II). The design used was a single group randomized design (RBD) with four treatments, each variety used was Bawor 9, Black Madras, M70, Sertani 8. All treatments were repeated 4 times. The results showed that the treatment of varieties affected plant height, number of tillers, panicle length, 1000 grain weight, harvest grain weight, milled dry grain weight, number of empty grain, number of filled grain and weight of stover.
\end{abstract}

Keywords: environmentally friendly, management, paddy rice

\section{ABSTRAK}

Sebagian besar petani padi sawah belum memberikan respon yang tepat terhadap inovasi pengelolaan sawah yang ramah lingkungan, karena kemampuan yang dimiliki petani belum mampu mendukung usahatani yang ramah lingkungan dan berkelanjutan. Kapasitas petani dalam mengelola padi sawah ramah lingkungan berhubungan erat dengan perilaku individu terhadap inovasi teknologi yang diterapkan dan didesiminasikan. Penelitian ini bertujuan untuk menentukan produktivitas padi sawah yang dikelola melalui pendekatan pengelolaan ramah lingkungan. Penelitian dilaksanakan di Kabupaten Merauke Provinsi Papua sejak bulan Juli sampai Nopember 2018 pada musim tanam gadu (MT II). Rancangan yang digunakan yaitu Rancangan Acak Kelompok (RAK) faktor tunggal dengan empat perlakuan, masing-masing varietas yang digunakan yaitu Bawor 9, Black Madras, M70, Sertani 8. Semua perlakuan diulang sebanyak 4 kali. Hasil penelitian menunjukan bahwa perlakuan varietas berpengaruh terhadap tinggi tanaman, jumlah anakan, panjang malai, bobot 1000 butir, bobot gabah panen, bobot gabah kering giling, jumlah gabah hampa, jumlah gabah bernas dan berat brangkasan.

Kata Kunci: padi sawah, pengelolaan, ramah lingkungan

\section{PENDAHULUAN}

Kebutuhan konsumen akan produk pertanian organik meningkat tajam seiring dengan tingginya kesadaran akan pentingnya faktor kesehatan, gaya hidup dan kepedulian terhadap lingkungan yang berkelanjutan (Dalmiyatun et al., 2018). Pentingnya hidup sehat dengan menggunakan produk hasil pertanian organik telah menjadi trend baru masyarakat di dunia karena masyarakat semakin sadar bahwa penggunaan bahanbahan kimia non-alami, seperti pupuk dan pestisida kimia sintetis dalam produksi pertanian, ternyata dapat berdampak negatif terhadap kesehatan manusia dan lingkungan hidup. Gaya hidup yang demikian ini telah mengalami pelembagaan secara internasional yang diwujudkan melalui regulasi perdagangan global yang mendorong adanya jaminan bahwa produk pertanian harus mempunyai atribut aman dikonsumsi (food safety attributes), memiliki kandungan nutrisi tinggi (nutritional attributes) serta ramah lingkungan (ecolabelling attributes) (Prihandarini, 2009).

Pertanian organik sangat dibutuhkan di Indonesia untuk mencapai ketahanan pangan, keamanan pangan, dan kelestarian lingkungan yang lebih baik dan untuk 
pengentasan kemiskinan (Hidayat dan Lesmana, 2011). Pertanian organik dengan cepat diakui di seluruh dunia sebagai salah satu cara yang menawarkan produk pangan sehat dan terjaminnya kelestarian lingkungan yang berkelanjutan. Saat ini, produk organik termasuk beras organik sangat diminati karena potensinya terkait dengan tingginya harga premium di pasar global (Hazra et al., 2018). Ada contoh-contoh bahwa pertanian organik dapat memberikan produktivitas lebih tinggi daripada pertanian konvensional; di sisi lain, pada saat yang sama produktivitas pertanian konvensional cenderung menurun.

Dalam implementasinya kajian ini merekomendasikan dua tahap dalam mengembangkan pertanian organik, yakni model skala kecil dalam jangka pendek dan model skala besar dalam jangka panjang. Dari pengalaman selanjutnya disarankan untuk mempromosikan pertanian organik dengan sistem pengelolaan secara intensifikasi, untuk mendapatkan hasil panen yang lebih tinggi. Meskipun komponen organik dalam tanah penting dalam proses siklus hara dalam agroekosistem, banyak kalangan meyakini bahwa produksi serealia secara nasional, regional, maupun dunia akan tetap mengandalkan pupuk kimia untuk dapat memenuhi kebutuhan produksi dan konsumsi saat ini dan masa mendatang (Dobermann, 2007; Mamaril, 2006; Fagi, 2005; Las, 2005).

Pendekatan pengelolaan padi sawah ramah lingkungan berhubungan erat dengan perilaku individu terhadap inovasi yang diadopsi. Bagi seorang petani menentukan suatu pilihan terhadap suatu inovasi merupakan proses panjang yang harus dilalui sebelum memutuskan untuk menerima maupun menolak inovasi tersebut. Keputusan inovasi merupakan suatu tipe pengambilan keputusan yang khas karena mereka harus memilih alternatif teknologi baru (inovasi) dan meninggalkan teknologi lama. Persepsi petani terhadap inovasi teknologi yang disampaikan menjadi penentu keberhasilan dalam proses adopsi inovasi. Adopsi inovasi teknologi budidaya tanaman padi di Sumatera Selatan misalnya dipengaruhi oleh tingkat kebutuhan petani terhadap inovasi teknologi, pengetahuan petani luas, mudah diterapkan, kompleksitas teknologi dan intensitas pembinaan. (Efendy dan Hutapea, 2010). Perilaku usahatani padi sawah masih menggambarkan kegiatan yang turun temurun dan konvensional karena pada generasi sebelumnya sebagian besar usahatani yang ada merupakan warisan orang tuanya. Penerapan inovasi yang ramah lingkungan dilakukan berupa Pengelolaan Tanaman Terpadu (PTT) dan Sistem Integrasi Padi Ternak (SIPT), program pertanian organik melalui penanaman padi pola System of RiceIntensification (SRI), Low External Input Sustainable Agriculture (LEISA/LISA) dan Pertanian Input Organik (IPO) (Istiantoro et al., 2013). Namun demikian sebagian besar petani padi sawah belum mampu memberikan respon yang tepat atas inovasi pengelolaan sawah yang ramah lingkungan.
Kemampuan atau kapasitas yang dimiliki petani belum mendukung untuk menghasilkan produk-produk usahatani yang ramah lingkungan dan berkelanjutan.

Luas areal tanam padi pada lahan sawah tahun 2018 di Merauke adalah 29.250 ha dengan produksi sebesar 208.206,38 $\mathrm{t}$ dan produktivitas 4,39 t/ha (BPS, 2018). Hal ini masih memberi peluang bagi upaya peningkatan produktivitas padi pada lahan sawah di Kabupaten Merauke. Upaya yang paling strategis adalah meningkatkan upaya intensifikasi. Peningkatan produksi padi selain ditujukan untuk memenuhi kebutuhan pangan penduduk juga agar menjadi sumber pendapatan rumah tangga petani produsen (Soehendi dan Syahri, 2014). Budidaya padi organik perlu dilakukan untuk mengurangi penggunaan bahan kimia secara terus menerus yang dapat menyebabkan tanah dan lingkungan tercemar. Menperkenalkan pestisida ramah lingkungan tidak mengandung bahan kimia yang telah tersedia cukup banyak pasaran. Sehingga pengelolaan sawah yang ramah lingkungan secara berkelanjutan dalam menghasilkan produksi usahatani untuk kelangsungan hidup. Untuk itu disamping upaya peningkatan produksi secara intensif, perlu juga dilakukan pendekatan melalui pengelolaan budidaya padi ramah lingkungan. Penelitian ini bertujuan untuk menentukan produktivitas padi sawah yang dikelola melalui pendekatan pengelolaan ramah lingkungan.

\section{BAHAN DAN METODE}

\section{Lokasi dan waktu penelitian}

Penelitian lapangan dilakukan di Kabupaten Merauke Provinsi Papua dari bulan Juli sampai Nopember 2018 pada musim gadu (musim tanam ke 2). Lokasi penelitian merupakan lokasi pengembangan padi Dinas Tanaman Pangan dan Hortikultura Kabupaten Merauke dan penentuannya dilakukan secara sengaja dalam rangka mendukung pengembangan lumbung pangan di wilayah perbatasan. Pelaksanaan pengkajian dilakukan di lahan petani melalui pendekatan On Farm Adaptive Research (OFAR), menggunakan lahan petani seluas 6 ha yang melibatkan kelompok Tani Suka Maju Distrik Tanah Miring Kampung Amungkay, SP 8.

\section{Bahan dan Alat}

Bahan yang digunakan adalah benih padi sawah yang terdiri atas 4 varietas, yaitu Bawor 9, Black Mdras, M70 dan Sertani 8; pupuk hayati Agrimet, dolomit, pupuk Petro Organik, biodekomfoser dan Bio pestisida. Alat-alat yang digunakan dalam penelitian ini meluputi: traktor tangan, hand spayer, cangkul, tali tanam dan combine harvester. 


\section{Metode Penelitian}

Penelitian menggunakan rancangan acak kelompok dengan satu faktor, yaitu varietas padi sawah, dengan 4 varietas yang diuji, yaitu: a) Bawor 9; b) Black Mdras; c) M70; dan d) Sertani 8. Petani sebagai ulangan luas petak percobaan untuk masing-masing perlakuan adalah $2.500 \mathrm{~m}^{2}$.

Jumlah benih $25 \mathrm{~kg} / \mathrm{ha}$, sebelum benih disemai pupuk hayati Agrimeth diaplikasikan dengan takaran 500 gram $/ 25 \mathrm{~kg}$ benih. Petak persemaian adalah sebesar $1 / 20$ luas penanaman. Pengolahan tanah secara sempurna dan sebelum dilakukan pengolahan tanah lahan terlebih dahulu disemprot dengan biodekomposer $2 \mathrm{~kg} / \mathrm{ha}$. Umur bibit muda adalah <21 hari setelah semai (HSS). Sistem tanam yang digunakan adalah legowo 4:1 dengan jarak tanam $20 \times 10 \times 40 \mathrm{~cm}$, yang merupakan teknologi unggulan Badan Litbang Kementan (Ikhwani et al., 2013). Sebelum tanam lahan tanam terlebih dahulu ditaburi pupuk Petro organik 2 t/ha sebagai pupuk dasar. Pemupukan berdasarkan rekomendasi kalender tanam terpadu, dilakukan sebanyak 3 kali selama musim tanam, yaitu pemupukan pertama pada umur 7-14 sari setelah tanam (HST), pemupukkan kedua pada umur 25-30 HST dan pemupukkan ketiga pada umur 45-50 HST. Pengendalian gulma dilakukan secara manual, sedangkan pengendalian hama dan penyakit dilaksanakan dengan prinsip Pengendalian Hama Terpadu (PHT) dengan menggunakan bio pestisida yang tersedia di toko pertanian yakni bio-pest dan biopestkiller dengan dosis 5-10 mL/15 L air dengan aplikasi 1 kali setiap minggu sampai hama penyakit terkendali.

Cara aplikasi dan pemanfaatan komponen perlakuan dapat dijelaskan sebagai sebagai berikut:

(1) Pupuk hayati Agrimet merupakan pupuk berbasis mikro non patogenik yang dapat menghasilkan fitohormon (zat pemacu tumbuh tanaman), penambat nitrogen dan membantu pelarutan fosfat yang berfungsi meningkatkan kesuburan dan kesehatan tanah. Aplikasi pupuk organik dilakukan pada pagi hari atau sore hari dengan sekali aplikasi pada saat benih akan disemai dengan cara perlakuan benih.

(2) Biodekomfoser yang merupakan komponen teknologi perombak bahan organik, diaplikasi 2 $\mathrm{kg} / \mathrm{ha}$, dicampur secara merata dengan $400 \mathrm{~L}$ air bersih. Larutan biodekomposer selanjutnya disemprotkan secara merata tunggul jerami pada petakan sawah (Badan Litbang Pertanian, 2016).

(3) Dolomit berfungsi untuk menurunkan keasaman tanah. Uji PUTS tanah tempat penelitian yang dilakukan sebelumnya menunjukkan $\mathrm{pH}$ 5,1, sehingga perlu dilakukan pemberian kapur pertanian (dolomit) sebelum dilakukan penanaman.

(4) biopestisida yang dipakai selama pengkajian: a) Bio-pest adalah pestisida hayati mengandung Beuvaria bassiana, Metarhizium anisophilae, dan pestisida nabati mengandung ekstrak Azadirachtin (daun mimba) Unsur hara esensial: N 6,5\%, P 5\%, K 5\% fungsinya mengendalikan berbagai macam hama serangga: belalang, walang sangit, kumbang, wereng cokelat, kepinding tanah, kwang kwung stadia larva, ulat grayak, kutu kebul, lalat buah, penggerek batang, tungau, Aphis sp., Myzus sp., Thrips, caplak, uret dan lain-lain; dan b) BiopestKiller adalah produk insectisida hayati, mengandung jamur Beauveria bassiana yang dapat menimbulkan penyakit terhadap serangga. Jamur ini bersifat parasit (tidak bisa memproduksi makanannya sendiri) sehingga hidup dari nutrisi inangnya, dengan cara menempel pada kulit, saluran pencernakan, spirakel atau lubang lainnya. Proses selanjutnya jamur berkembangbiak, mengeluarkan toksin dan membunuh serangga fungsinya mengendalikan hama-hama tanaman Wereng coklat, Wereng hijau, Wereng punggung putih, Walang sangit, Kepinding tanah, Kepik hijau, Kepik polong, Kutu daun, Ulat grayak, Kutu putih (PT Centra Biotech Indonesia, 2015).

Peubah-peubah yang diamati adalah:

Data pertumbuhan dan komponen hasil diambil berdasarkan rata-rata 10 tanaman contoh tiap petak ubinan, meliputi a) tinggi tanaman; b) jumlah anakan per rumpun; c) jumlah gabah bernas per malai; d) jumlah gabah hampa per malai; dan e) jumlah gabah total per malai.

Hasil gabah kering panen per petak ditimbang secara ubinan $(2,5 \mathrm{~m} \times 2,5 \mathrm{~m})$ sebanyak 10 sampel per petak dengan melibatkan Badan pusat Statistik (BPS), kemudian dikonversikan ke hektar.

\section{Analisis Data}

Data diolah menggunakan aplikasi DSAASTAT ver. 1.101. Analisis sidik ragam dilakukan untuk mendapatkan nilai uji $\mathrm{F}$ pada taraf $5 \%$ dan jika terdapat pengaruh nyata dilanjutkan analisis lanjut dengan uji Duncan. Untuk menghitung presentasi data menggunakan rumus yang dikemukakan oleh Hermawan (2015):

Presentasi data $=(($ Jumlah akhir - Jumlah awal $) /$ Jumlah awal) $\times 100 \%$

\section{HASIL DAN PEMBAHASAN}

Komponen teknologi penting yang memiliki kontribusi besar dalam meningkatkan produktivitas dan pendapatan usahatani padi salah satu adalah varietas unggul. Selain hal tersebut komponen pengelolaan usahatani dan budidaya tanaman yang baik juga merupakan komponen penting dalam meningkatkan pertumbuhan dan perkembangan tanaman menjadi lebih baik sehingga dapat berproduksi sesuai dengan yang diharapkan. Komponen teknologi tersebut sangat 
berperan dalam mengubah sistem usahatani padi sawah dari subsistem menjadi komersial.

Pertumbuhan tanaman masa vegetatif hingga generatif menunjukan penampilan beragam sampai panen, namun secara keseluruhan dapat beradaptasi dengan baik. Pada saat tanaman berumur 30 HST sampai 50 HST terdapat hama putih dan wereng hijau pada semua varietas, dan saat keluar malai terdapat hama walang sangit. Setelah dilakukan pengendalian dengan penyemprotan bio pestisida tanaman kembali pulih dari hama putih dan walang sangit.

\section{Komponen Pertumbuhan Tanaman}

\section{Tinggi Tanaman}

Pada Tabel 1 dapat dilihat bahwa tinggi tanaman di antara varietas-varietas yang diuji bervariasi pada berbagai umur pengamatan 30 HST sampai 90 HST dan secara statistik berbeda nyata. Pada umur 30 HST ada tiga varietas yang tinggi tanamannya sama, yaitu Bawor 9, M70, Sertani 8. Pada pengamatan menjelang panen 90 HST tinggi tanaman tertinggi dicapai oleh Sertani 8, sedangkan yang terendah M70.

Tanaman yang relatif tidak terlalu tinggi dapat terhindar dari kerebahan yang disebabkan oleh angin kencang. Tanaman yang rebah dapat menurunkan hasil gabah (Sutaryo dan Sudaryono, 2012). Menurut Endrizal dan Bobihoe (2010), tinggi tanaman merupakan salah satu kriteria seleksi tanaman padi. Tinggi rendahnya tanaman berkaitan dengan ketahanan rebah. Tanaman yang terlalu tinggi umumnya mudah rebah. Oleh sebab itu, tinggi tanaman menentukan penerimaan petani terhadap suatu varietas unggul baru. Petani umumnya kurang menyukai varietas dengan postur tinggi karena produktivitasnya belum tentu tinggi.

\section{Jumlah Anakan}

Sebagaimana pada Tabel 2, hasil analisis menunjukan jumlah anakan berbeda nyata pada semua umur pengamatan. Pada keempat varietas yang diuji, pada umur 30 HST jumlah anakan tertinggi terdapat pada Bawor 9 disusul M70, Sertani 8 dan terkecil Black
Madras. Namun yang menjadi anakan produktif yang bisa menghasilkan malai pada pengamatan terakhir sebelum panen pada umur 90 HST terdapat pada varietas Bawor 9 sebanyak 15,8 anakan (14,8\%), disusul M70 dengan 14,6 anakan (12,2\%), Black Madras dengan 13,2 anakan $(13,6 \%)$ dan Sertani 8 dengan hanya 9 anakan (8\%). Untuk mendapatkan presentase jumlah anakan yakni hasil pengamatan terakhir dikurangi pengamatan awal dibagi pengamatan awal dikalikan $100 \%$.

Menurut Yartiwi et al. (2018), anakan produktif merupakan anakan yang menghasilkan malai sebagai tempat kedudukan biji atau bulir padi. Varietas unggul baru biasanya mempunyai 20-25 anakan, namun hanya 14-15 anakan yang malainya dapat dipanen, dengan jumlah gabah per malai $100-130$ butir. Hal ini disebabkan anakan yang tumbuh belakangan terlambat masak sehingga tidak dapat dipanen. Anakan utama juga cenderung menghasilkan gabah yang lebih tinggi dari anakan kedua, ketiga dan seterusnya.

Hasil penelitian lapang di Cimalaka, Sumedang, Jawa Barat, menunjukkan bahwa padi yang ditanam dengan 3-5 bibit per lubang, hanya menghasilkan anakan sekitar 20 anakan per lubang, yang ditanam dengan 2 bibit per lubang menghasilkan anakan sekitar 25 anakan per lubang, dan yang ditanam dengan 1 bibit per lubang mampu menghasilkan sekitar 30 anakan per lubang (Simarmata dan Sinaga, 2006). Diindikasikan bahwa makin banyak jumlah bibit akan menyebabkan terjadinya persaingan di antara bibit tanaman padi untuk memperoleh nutrisi dan faktor tumbuh lainnya.

Jumlah anakan produktif per rumpun atau per satuan luas merupakan penentu terhadap jumlah malai yang merupakan salah satu komponen hasil yang berpengaruh langsung terhadap tinggi rendahnya hasil gabah (Simanulang, 2001). Semakin banyak anakan produktif maka semakin banyak jumlah malai yang terbentuk. Terdapat korelasi antara jumlah malai dengan hasil karena semakin banyak jumlah malai semakin tinggi juga hasil tanaman padi. Hal ini hampir sama dengan hasil penelitian Muliadi dan Pratama (2008), menunjukkan bahwa jumlah malai berkorelasi positif nyata terhadap hasil tanaman.

Tabel 1. Rata-rata tinggi tanaman pada berbagai varietas padi di Kabupaten Merauke, Musim Gadu 2018

\begin{tabular}{lccccc}
\hline \multirow{2}{*}{ Varietas } & \multicolumn{5}{c}{ Tinggi tanaman $(\mathrm{cm})$} \\
\cline { 2 - 6 } & $30 \mathrm{HST}$ & $45 \mathrm{HST}$ & $60 \mathrm{HST}$ & $75 \mathrm{HST}$ & $90 \mathrm{HST}$ \\
\hline Bawor 9 & $74,2 \mathrm{a}$ & $86,8 \mathrm{~b}$ & $102,6 \mathrm{~b}$ & $107,6 \mathrm{~b}$ & $107,6 \mathrm{~b}$ \\
Black Madras & $58,0 \mathrm{~b}$ & $82,0 \mathrm{~b}$ & $90,0 \mathrm{c}$ & $95,0 \mathrm{c}$ & $95,0 \mathrm{c}$ \\
M 70 & $74,2 \mathrm{a}$ & $80,4 \mathrm{~b}$ & $91,0 \mathrm{c}$ & $91,0 \mathrm{c}$ & $91,0 \mathrm{c}$ \\
Sertani 8 & $74,2 \mathrm{a}$ & $111,6 \mathrm{~b}$ & $138,8 \mathrm{c}$ & $138,8 \mathrm{a}$ & $138,8 \mathrm{a}$ \\
\hline LSD 0,05 & 3,35 & 12,22 & 11,56 & 8,33 & 3,82 \\
\hline CV (\%) & 3,47 & 9,84 & 7,95 & 5,59 & 5,59 \\
\hline
\end{tabular}

Keterangan: Angka-angka yang diikuti huruf yang sama pada kolom yang sama menunjukkan tidak berbeda nyata berdasarkan uji lanjut LSD pada taraf $5 \%$. 
Tabel 2. Rata-rata jumlah anakan pada berbagai varietas padi di Kabupaten Merauke, Musim Gadu 2018

\begin{tabular}{lccccc}
\hline \multirow{2}{*}{ Perlakuan } & \multicolumn{5}{c}{ Jumlah anakan } \\
\cline { 2 - 5 } & $30 \mathrm{HST}$ & $45 \mathrm{HST}$ & $60 \mathrm{HST}$ & 75 HST & 90 HST \\
\hline Bawor 9 & $21,6 \mathrm{a}$ & $18,2 \mathrm{~b}$ & $16 \mathrm{a}$ & $15,8 \mathrm{a}$ & $15,8 \mathrm{a}$ \\
Black Madras & $11,4 \mathrm{~b}$ & $15,8 \mathrm{~b}$ & $14 \mathrm{a}$ & $13,2 \mathrm{a}$ & $13,2 \mathrm{a}$ \\
M 70 & $14,8 \mathrm{~b}$ & $18,2 \mathrm{~b}$ & $14,6 \mathrm{a}$ & $14,6 \mathrm{a}$ & $14,6 \mathrm{a}$ \\
Sertani 8 & $12,6 \mathrm{~b}$ & $11 \mathrm{~b}$ & $9 \mathrm{~b}$ & $9 \mathrm{~b}$ & $9 \mathrm{~b}$ \\
\hline LSD 0,05 & 3,78 & 4,08 & 3,72 & 3,68 & 3,68 \\
\hline CV (\%) & 18,2 & 18,78 & 20,2 & 20,36 & 20,36 \\
\hline
\end{tabular}

Keterangan: Angka-angka yang diikuti huruf yang sama pada kolom yang sama menunjukkan tidak berbeda nyata berdasarkan uji lanjut LSD pada taraf $5 \%$.

Tabel 3. Rata-rata panjang malai, jumlah gabah per malai, jumlah gabah bernas per malai, jumlah gabah hampa pada berbagai varietas padi di kabupaten Merauke, Musim Gadu 2018

\begin{tabular}{|c|c|c|c|c|}
\hline Varietas & Panjang Malai & $\begin{array}{c}\text { Jumlah Gabah per } \\
\text { Malai }\end{array}$ & $\begin{array}{l}\text { Jumlah Gabah Isi } \\
\text { bernas per Malai }\end{array}$ & Jumlah Gabah Hampa \\
\hline Bawor 9 & $25,60 \mathrm{ab}$ & $132,60 \mathrm{~b}$ & $112,20 \mathrm{a}$ & $20,40 \mathrm{a}$ \\
\hline Black Madras & $24,30 b$ & $130,60 b$ & $119,80 \mathrm{a}$ & $10,80 \mathrm{c}$ \\
\hline M 70 & $22,40 \mathrm{~b}$ & $100,80 b$ & $87 b$ & $13,80 \mathrm{bc}$ \\
\hline Sertani 8 & $28,40 \mathrm{a}$ & $175,20 \mathrm{a}$ & $119,40 \mathrm{a}$ & $55,80 \mathrm{a}$ \\
\hline LSD 0,05 & 3,03 & 40,12 & 35,36 & 7,94 \\
\hline $\mathrm{CV}(\%)$ & 8,76 & 21,2 & 23,42 & 22,88 \\
\hline
\end{tabular}

Keterangan: Angka-angka yang diikuti huruf yang sama pada kolom yang sama menunjukkan tidak berbeda nyata berdasarkan uji lanjut LSD pada taraf 5\%.

\section{Komponen Hasil}

Hasil pengamatan dan analisis terhadap panjang malai, jumlah gabah per malai, jumlah gabah isi bernas per-malai dan jumlah gabah hampa dapat dilihat pada Tabel 3. Hasil analisis menunjukkan panjang malai berbeda sangat nyata antara varietas Sertani 8 dengan ketiga varietas lainnya yang diuji. Rata-rata panjang malai pada varietas Sertani 8 adalah $28,40 \mathrm{~cm}$, Bawor 9 $25,50 \mathrm{~cm}$, Black Madras 24,30 $\mathrm{cm}$ dan yang terpendek M70 22,40 cm. Potensi hasil suatu varietas padi ditentukan oleh empat komponen, yaitu panjang malai, jumlah gabah per malai, persentase gabah isi, gabah hampa dan berat 1000 butir gabah (Yoshida et al, 2012). Hasil pengkajian menunjukkan bahwa makin berat bobot gabah maka makin tinggi produktivitasnya. Jumlah gabah per-malai secara statistik berbeda nyata antara varietas Sertani 8 dengan varietas Bawor 9, Black Madras dan M70. Namun jumlah gabah per malai di antara Bawor 9, Black Madras dan M70 tidak berbeda nyata satu sama lain. Ke empat varietas yang diuji pada jumlah gabah isi per-malai menunjukan bahwa Sertani 8, Bawor 9, Black Madras berbeda nyata dengan M70. Sedangkan antara varietas Sertani 8, Bawor 9 dan M70 tidak terdapat perbedaan nyata. Persentase gabah bernas dan gabah hampa tertinggi adalah pada varietas Black Madras [91,71\% atau 119,80 butir] dan pada varietas Sertani 8 [68,15\% atau 119,40 butir]. Berdasarkan data jumlah gabah hampa dan dengan mempertimbangkan jumlah gabah total pada varietas padi yang diuji, maka hasil gabah dari varietas-varietas padi tersebut bisa ditingkatkan lagi, dengan lebih mengoptimalkan takaran pupuk dan cara pemupukan yang lebih tepat (Rustiati dan Abdulrachman, 2011). Hasil gabah juga masih dapat ditingkatkan dengan mengoptimalkan tanam jajar legowonya, karena dengan pengaturan jarak tanam yang tepat kondisi pencahayaan matahari dan radiasi surya yang optimal dapat meningkatkan produktivitas padi (Hermanto, 2007).

Persentase gabah bernas dan gabah hampa terendah dihasilkan pada varietas M70 [86,31\% atau 87 butir] dan Black Madras [8,27 \% atau 10,8 butir]. Rendahnya jumlah gabah per malai yang dihasilkan ini disebabkan panjang malainya relative pendek atau dibawah deskripsinya. Panjang malai berkorelasi positif dengan jumlah gabah yang dihasilkan. Semakin panjang malai maka gabah yang dihasilkan semakin banyak. Jumlah gabah bernas per malai berkorelasi nyata dengan hasil gabah, karena jumlah gabah bernas per malai merupakan salah satu komponen hasil yang menentukan bobot gabah (Endrizal dan Bobihoe, 2010).

Pada Tabel 4 dapat dilihat bahwa untuk peubah berat 1000 bulir terdapat perbedaan antar varietas yang sangat nyata. Pada varietas Sertani 8 (34,22 g) dengan ke tiga varietas namun tidak berbeda nyata Blak Madras $(25,34 \mathrm{~g})$ dan M70 (25,88 g). Jumlah gabah bernas yang cukup banyak merupakan salah satu faktor penentu tingginya hasil yang diperoleh (Sutaryo, 2012). 
Tabel 4. Berat 1000 butir, gabah kering panen, gabah kering giling dan berat biomasa pada berbagai varietas padi di Kabupaten Merauke, Musim Gadu 2018

\begin{tabular}{lcccc}
\hline \multicolumn{1}{c}{ Perlakuan } & Berat 1000 butir & $\begin{array}{c}\text { Gabah Kering } \\
\text { Panen (t/ha) }\end{array}$ & $\begin{array}{c}\text { Gabah Kering } \\
\text { Giling (t/ha) }\end{array}$ & Berat Biomasa (t/ha) \\
\hline Bawor 9 & $31,42 \mathrm{~b}$ & $4 \mathrm{c}$ & $3,1 \mathrm{c}$ & $7,10 \mathrm{c}$ \\
Black Madras & $25,34 \mathrm{c}$ & $3,20 \mathrm{~d}$ & $2,42 \mathrm{~d}$ & $5,44 \mathrm{~d}$ \\
M 70 & $25,88 \mathrm{c}$ & $4,82 \mathrm{a}$ & $3,62 \mathrm{a}$ & $9,48 \mathrm{~b}$ \\
Sertani 8 & $34,22 \mathrm{a}$ & $4,50 \mathrm{~b}$ & $3,42 \mathrm{~b}$ & $17,24 \mathrm{a}$ \\
\hline LSD 0,05 & 0,55 & 0,26 & 0,10 & 0,57 \\
\hline CV (\%) & 1,37 & 4,59 & 2,53 & 4,25 \\
\hline
\end{tabular}

Keterangan: Angka-angka yang diikuti huruf yang sama pada kolom yang sama menunjukkan tidak berbeda nyata berdasarkan uji lanjut LSD pada taraf $5 \%$

Hasil sidik ragam terhadap gabah kering panen (GKP) menunjukkan adanya perbedaan nyata antar varietas. Hasil gabah berkisar antara 4 dan 4,82 t GKP/ha, dengan hasil gabah tertinggi terdapat pada varietas M70 (4,82 t GKP/ha) yang berbeda nyata dengan Sertani 8 (4,50 t GKP/ha), Bawor 9 ( $4 \mathrm{t}$ GKP/ha) dan Black Madras (3,20 t GKP/ha).

Hasil sidik ragam terhadap gabah kering giling (GKG) dengan kadar air 12\% juga menunjukkan adanya perbedaan nyata antar varietas. Hasil gabah berkisar antara 2,42 dan 3,62 t GKG/ha. Hasil gabah tertinggi terdapat pada varietas M70 (3,62 t GKG/ha), yang berbeda nyata dengan tiga varietas lainnya, yakni Sertani 8 (3,42 t GKG/ha), Bawor 9 (3,10 t GKG/ha) dan Black Madras (2,42 t GKG/ha). Menurut Setiobudi et al. (2009), banyaknya gabah selain ditentukan oleh banyaknya malai yang dihasilkan juga oleh proses diferensiasi spikelet, penyerbukan dan fertilisasi. Berkurangnya pasokan asimilat, dimensi ukuran dan percabangan malai dapat mengurangi potensi gabah yang dihasilkan. Pengisian gabah dipengaruhi oleh suhu udara, dimana semakin tinggi suhu udara laju pengisian gabah makin cepat, namun distribusi pengisian gabah tidak merata sehingga mengakibatkan pengisian gabah tidak penuh (Setiobudi et al., 2009).

Berat biomasa berbeda sangat nyata di antara varietas-varietas yang diuji, berkisar antara 5,44 dan 17,24 brangkasan t/ha. Berat brangkasan jerami tertinggi terdapat pada Sertani $8(17,24 \mathrm{t} / \mathrm{ha})$, disusul M70 (9,48 t/ha), Bawor 9 (7,10 t/ha) dan terendah Black Madras (5,44 t/ha). Brangkasan jerami dapat dijadikan pakan ternak, namun dapat juga dikembalikan ke sawah untuk dikomposkan menjadi pupuk organik. Penggunaan kompos jerami padi tidak hanya meningkatkan ketersediaan hara juga mampu memperbaiki sifat fisik tanah yang menguntungkan bagi pertumbuhan tanaman.

\section{KESIMPULAN}

Pengkajian pengelolaan usahatani padi sawah dengan pendekatan ramah lingkungan menggunakan empat varietas padi sawah, yaitu Bawor 9, Black Mdras, M70 dan Sertani 8, menunjukkan adanya perbedaan yang nyata antar varietas pada komponen pertumbuhan maupun komponen hasil. Pada pertumbuhan tinggi tanaman tertinggi Sertani 8 dan terendah M70 kemudian jumlah anakan produktivif paling banyak Bawor 9. Komponen hasil tertinggi panjang malai, jumlah gabah per-malai, berat 1000 butir, berat biomasa yaitu varietas Sertani 8. Gabah isi bernas tertinggi black madras dan gabah kering giling (GKG/ha) produksi tertinggi varietas M70.

\section{UCAPAN TERIMA KASIH}

Ucapan terima kasih disampaikan kepada: Badan Penelitian dan Pengembangan Pertanian, Kementerian Pertanian, yang telah memberikan bantuan dana sehingga penelitian ini dapat terlaksana; Dr. Ir. Yuliantoro Baliadi selaku Kepala Balai Pengkajian Teknologi Pertanian Papua (periode 20152018); serta Tim Kebun Percobaan Merauke, yaitu Rodias Beda Legu, Nely Malla dan Sriyati sebagai teknisi penelitian dan rekayasa yang telah membantu dalam mengamati dan mengumpulkan data selama pengkajian berlangsung.

\section{DAFTAR PUSTAKA}

Badan Litbang Pertanian. 2016. Petunjuk Teknis Budidaya Padi Jajar Legowo Super. Kementerian Pertanian. 19 hal.

[BPS] Badan Pusat Statistik. 2018. Laporan Badan Pusat Statistik Merauke. BPS Merauke.

Dalmiyatun, T., B.T. Eddy, W. Sumekar, D. Mardiningsih. 2018. Motivation of farmers to cultivate organic rice in central java. IOP Conference Series: Earth and Environmental Science 102 012043. DOI: 10.1088/17551315/102/1/012043.

Dobermann, A. 2007. Can organic agriculture or SRI feed Asia? IRRI, Los Banos, Philippines.

Efendy, J. dan Y. Hutapea. 2010. Analisis adopsi inovasi teknologi pertanian berbasis padi di Sumatera Selatan dalam perspektif komunikasi. Jurnal Pengkajian dan Pengembangan 
Teknologi Pertanian 13: 119-130. DOI: 10.21082/jpptp.v13n2.2010.p\%25p

Endrizal, dan J. Bobihoe. 2010. Pengujian beberapa galur unggulan padi dataran tinggi di Kabupaten Kerinci Propinsi Jambi. Jurnal Pengkajian dan Pengembangan Teknologi Pertanian 13: 175184. DOI: $10.21082 /$ jpptp.v13n3.2010.p\%25p

Fagi, A.M. 2005. Menyikapi Gagasan Dan Pengembangan Pertanian Organik Di Indonesia. Seri AKTP No. 1/2005. Badan Penelitian dan Pengembangan Pertanian.

Hazra, K.K., D. K. Swain, A. Bohra, S.S. Singh, N. Kumar, and C.P. Nath. 2018. Organic rice: potential production strategies, challenges and prospects. Organic Agriculture 8: 39-56. DOI: 10.1007/s 13165-016-0172-4

Hermanto. 2007. PTT andalan peningkatan produksi padi nasional. Warta Penelitian dan Pengembangan Pertanian Indonesia 26: 14-15.

Hidayat, A.S. dan T. Lesmana. 2011. The development of organic rice farming in Indonesia. RIEBS 2.

Hermawan. 2015. Aplikasi Statistik Pada Data Pendampingan Untuk Karya Tulis Ilmiah. Badan Penelitian Dan Pengembangan. Jakarta. IAARD Prees 2015.

Ikhwani, G.R. Pratiwi, E. Paturrohman, dan A.K. Makarim. 2013. Peningkatan produktivitas padi melalui penerapan jarak tanam jajar legowo. IPTEK Tanaman Pangan 8: 72-79.

Istiantoro, N. Bambang, A. Soeprobowati, dan T. Retnaningsih. 2013. Analisis faktor-faktor sosial ekonomi yang mempengaruhi pengendalian hama dan penyakit padi sawah ditinjau dari sistem pertanian berkelanjutan. Ekosains 5: 1620.

Las, I. 2005. Sudah perlukah padi organik? Warta Litbang Pertanian No.3/2005. Badan Penelitian dan Pengembangan Pertanian, Jakarta.

Mamaril, C.P. 2004. Organic fertilizer in rice: Myths and Facts. Agriculture 8: 12-13.

Muliadi A, dan R.H. Pratama. 2008. Korelasi antara komponen hasil dan hasil galur harapan padi sawah tahan tungro. Prosiding Seminar Nasional Padi; Inovasi Teknologi Padi Mengantisipasi Perubahan Iklim Global mendukung Ketahanan Pangan. pp. 165-171. Balai Besar Penelitian Tanaman Padi. Sukamandi.

Prihandarini, R. 2009. Potensi Pengembangan Pertanian Organik. Disampaikan saat Temu Lapang Petani Organik se Indonesia (Jambore Petani Organik) Boyolali, 7-9 April 2009.
PT Centra Biotech Indonesia. 2015. Pestisida Hayati Nabati. http://pestisida hayati nabati.blogspot.com/2015/10/produsen-jualdistributor- diakses 23 Januari 2019.

Rustiati, T., dan S. Abdulrachman. 2011. Komparatif Beberapa Metode Penetapan Kebutuhan Pupuk Adaptasi Varietas dan Evaluasi Kebutuhan Pupuk Padi Gogo pada Tanaman Padi. Prosiding Seminar Ilmiah Hasil Penelitian Padi Nasional 2010. Buku 2. Balai Besar Penelitian Tanaman Padi. Badan Penelitian dan Pengembangan Pertanian.

Setiobudi, D., Y. Samaullah, dan T. Rustiati. 2009. Kepekaan Relatif Padi Inbrida dan Hibrida Terhadap Variasi Pasokan Air Selama Fase Vegetatif dan Reproduktif Inovasi Teknologi Padi untuk Mempertahankan Swasembada dan Mendorong Ekspor Beras. Buku 2. Balai Besar Penelitian Padi. Sukamandi. p. 683-700.

Simanulang, Z.A. 2001. Kriteria Seleksi untuk Sifat Agronomis dan Mutu. Pelatihan dan Koordinasi Progam Pemuliaan Partisipatif (Shuttle Breeding) dan Uji Multilokasi. Sukamandi 9-14 April 2001. Balai Penelitian Padi. Sukamandi.

Simarmata, T. dan Y.H. Sinaga. 2006. Teknologi Peningkatan Produksi ABG (TPP-ABG) Berbasis Organik. Jakarta: PT. Gateway Internusa.

Soehendi, R., dan Syahri. 2014. Kesesuaian Varietas Unggul Baru Padi di Sumatera Selatan. Prosiding Seminar Nasional Inovasi Teknologi Pertanian Spesifik Lokasi. Medan, 6-7 Juni 2013.

Sutaryo, B. 2012. Ekspresi daya hasil dan beberapa karakter agronomi enam padi hibrida indica di lahan sawah berpengairan teknis. Ilmu Pertanian 15(2): 19-29. DOI: 10.22146/ipas. 2513

Sutaryo, B., dan T. Sudaryono. 2012. Tanggap Sejumlah Genotipe Padi Terhadap Tiga Tingkat Kepadatan Tanaman. Jurnal Pertanian AGROS 14.

Yartiwi, A. Damiri, I.C. Siagian, dan H. Iswadi. 2018. Keragaan Hasil Varietas Unggul Baru (Vub) Padi Sawah Lahan Sawah Tadah Hujan pada Dua Musim Tanam yang Berbeda di Kabupaten Seluma Provinsi Bengkulu. Prosiding Seminar Nasional Lahan Suboptimal 2018. "Tantangan dan Solusi Pengembangan PAJALE dan Kelapa Sawit Generasi Kedua (Replanting) di Lahan Suboptimal Prosiding Seminar Nasional Lahan Suboptimal 2018, Palembang 18-19 Oktober 2018. Pp. 216-224. 